The University of Maine

DigitalCommons@UMaine

Publications

Senator George J. Mitchell Center for Sustainability

Solutions

6-2016

\title{
Environmental Communication Pedagogy for Sustainability: Developing Core Capacities to Engage with Complex Problems
}

Bridie McGreavy

University of Maine Main, bridie.mcgreavy@maine.edu

Caroline Gottschalk Druschke

University of Rhode Island

Leah Sprain

University of Colorado Boulder

Jessica L. Thompson

Northern Michigan University

Laura A. Lindenfeld

Stony Brook University

Follow this and additional works at: https://digitalcommons.library.umaine.edu/ mitchellcenter_pubs

\section{Repository Citation}

McGreavy, Bridie; Gottschalk Druschke, Caroline; Sprain, Leah; Thompson, Jessica L.; and Lindenfeld, Laura A., "Environmental Communication Pedagogy for Sustainability: Developing Core Capacities to Engage with Complex Problems" (2016). Publications. 98.

https://digitalcommons.library.umaine.edu/mitchellcenter_pubs/98

This Article is brought to you for free and open access by DigitalCommons@UMaine. It has been accepted for inclusion in Publications by an authorized administrator of DigitalCommons@UMaine. For more information, please contact um.library.technical.services@maine.edu. 
Environmental communication pedagogy for sustainability: Developing core capacities to engage with complex problems

Bridie McGreavy ${ }^{a}$, Caroline Gottschalk Druschke ${ }^{b, c}$, Leah Sprain ${ }^{d}$, Jessica L. Thompson ${ }^{e}$, and Laura A. Lindenfeld

${ }^{a}$ Department of Communication and Journalism, University of Maine, Orono, Maine, USA;

${ }^{\mathrm{b}}$ Department of Writing \& Rhetoric, University of Rhode Island, Kingston, Rhode Island, USA;

${ }^{\mathrm{c}}$ Department of Natural Resources Science, University of Rhode Island, Kingston, Rhode Island, USA;

${ }^{\mathrm{d}}$ Department of Communication, University of Colorado Boulder, Boulder, Colorado, USA;

${ }^{\mathrm{e}}$ Communication and Performance Studies Department, Northern Michigan University, Marquette, Michigan, USA;

${ }^{\mathrm{f}}$ Alan Alda Center for Communicating Science, School of Journalism, Stony Brook University, Stony Brook, New York, USA 


\begin{abstract}
Pedagogy informed by environmental communication can enhance collaboration within and outside the classroom. Through our collaborative, sustainability-focused work within the United States and internationally, we identified core capacities that prepare people to work together to form inclusive organizations and identify and respond to pressing socioecological problems. We describe six activities we have used in adult learner classrooms, on interdisciplinary and transdisciplinary research teams, and with organizational, governmental, and business partners to improve collaborations for sustainability-related problem solving. We conclude with a reflection on opportunities for situated assessment practices.
\end{abstract}


Introduction

The field of environmental communication (EC) demonstrates a commitment to teaching and doing research in ways that improve understanding and promote transformation of complex social and environmental problems (Cox, 2007; Endres, Sprain \& Petersen, 2008; Lindenfeld, Hall, McGreavy, Silka, \& Hart, 2012;Sprain \& Timpson, 2012). Based on our experiences, we demonstrate that EC pedagogy can enhance collaboration and problem solving for students and community partners in ways that support sustainability outcomes. Our pedagogy mirrors our research and outreach — it is collaborative, transdisciplinary, and use-inspired. When students engage with community partners and hear about teacher-practitioners' applied work across civic and educational contexts, they learn how to integrate EC capacities in their future civic engagement and careers. Cross-pollinating EC pedagogy by using collaborative learning activities in diverse contexts strengthens our ability to realize praxis-based commitments and foster core capacities in our students, our community partners, and ourselves.

Here we briefly introduce the settings where we employ collaborative learning activities and discuss how these activities promote skills and practices central to EC praxis commitments, including critical reflection, environmental and scientific literacy, interpersonal communication capacities, and systems thinking (Table 1). We see these commitments as central to collaborative praxis, an ancient concept that emphasizes embodied practical wisdom (Haskins, 2006). The pedagogy and activities described as follows are designed to enhance individual critical reflection and problem-solving skills (Sprain \& Timpson, 2012); encourage positive interpersonal interactions within groups (Thompson, 2009); and promote knowledge coproduction 
processes and intentional change in organizations, situations, and socioecologies (Burke et al., 2016; Druschke \& Hychka, 2015;McGreavyetal., 2015). Tailored learning activities focused on developing specific communication practices, enhance collaboration (Thompson, 2009).

Pedagogical cross pollination for EC capacities

Working in different contexts, we have developed activities to support collaborative practices in interdisciplinary and transdisciplinary dispositions in classrooms and community settings in Colorado, Maine, Michigan, Rhode Island, and beyond. In Colorado, Sprain advances local democracy through improved public communication and community problem solving (see Carcasson, 2010; Carcasson \& Sprain, 2016). Many of the initiatives she works on require equipping nonscience students to guide conversation about water conflict, local food systems, regional growth, or climate change while simultaneously developing deliberative designs (Sprain, Carcasson, \& Merolla, 2014) for engaging community members. In Maine, McGreavy and Lindenfeld's EC research and pedagogy within statewide sustainability science networks supports teams of faculty, students, and diverse institutional partners as they develop solutions to pressing socioenvironmental problems related to water quality and public health, landscape change, and natural resource-based livelihoods (Lindenfeld et al., 2012;McGreavyetal., 2015). Based in Michigan and with projects that extend to national and international contexts, many of Thompson's collaborative projects address natural resource conservation related to climate change impacts (Cobb \& Thompson, 2012; Lemieux, Thompson, Slocumbe, \& Schuster, 2015). In all cases, a diverse set of stakeholders is engaged in an effort to represent various degrees of decision-making authority and scientific expertise, including local (or indigenous) knowledge 
(Rudeen, Fernandez-Gimenez, Thompson, \& Meiman, 2012; Thompson, Forster, Werner, \& Peterson, 2010). In Rhode Island, Gottschalk Druschke builds EC competencies into courses in rhetoric and restoration, partnerships with the U.S. Environmental Protection Agency (USEPA) and the National Park Service, and community engagement activities, emphasizing deliberate design (Druschke \& Seltzer, 2012; Druschke, Bolinder, Pittendrigh,\& Rai, 2015) of communication-centered stakeholder engagement (Druschke \& Hychka, 2015).

Our classroom and community-based work shape one another. For example, Thompson has found that students find an activity more relevant and interesting when she explains how she recently used it with a community group. Gottschalk Druschke has seen that connecting students with federal scientists from USEPA, the National Park Service, and the National Oceanic and Atmospheric Administration (NOAA) in classrooms, state offices, and coastal communities promotes meaningful learning-by-doing. McGreavy, Sprain, and Lindenfeld have experienced the value of involving students in interdisciplinary research teams where students as collaborators work with faculty and community partners to build adaptive capacities to changes in land use and climate. Across these contexts, EC's emphasis on inter-personal and group communication practices helps collaborators learn from each other through generative dialogue (Daniels \& Walker, 2001), while the discipline's commitment to crisis intervention informs collective orientations toward action (Cox, 2007).

Collaborations within diverse contexts 
Our EC teaching and research occurs in settings where we intentionally design collaborations for adult learners to ask questions, identify problems, design research and action plans, and advance projects. Complex sustainability problems like climate change, global poverty and systemic inequality, and toxic contamination of land and water require collaborations for inclusive decision making and effective policy (Daniels \& Walker, 2001; Depoe, Delicath, \& Elsenbeer, 2004; Tilbury and Wortman, 2008). Collaborations allow participants to understand complex social and environmental problems from multiple perspectives and build relationships to address these problems. Across our contexts, we aim to promote interdisciplinarity as an emergent phenomenon that occurs when collaborators find ways to integrate "information, data, methods, tools, concepts, or theories from two or more disciplines or bodies of knowledge to address a complex question, problem, topic, or theme" (Klein, 2014, p. 13). This integration is a hallmark of transdisciplinarity, which is "marked by shared interest in a particular matter or problem but often draws together radically different approaches" (Hawhee, 2009, p. 3). Transdisciplinarity is the realization of interdisciplinary-enriched knowledge for improved decision making in crossscale community and policy contexts.

Scholarship focused on practical training in communication for interdisciplinary and transdisciplinary collaborations informs our pedagogy (O’Rourke et al., 2014), but our work differs in two important ways. First, while research on interdisciplinarity, community-university partnerships, and team science frequently emphasizes how communication shapes collaborations, relatively few studies are situated in communication scholarship. EC offers vital perspectives on how communication shapes our understandings and actions in relation to social and environmental problems (Cox \& Depoe, 2015). Second, our activities create spaces where 
learning and skill development are practiced to cultivate knowledge. This comes through the labor, the work, and working through, that is always embedded within and a necessary part of collaborative learning (Daniels \& Walker, 2001). We understand this work as phronesis, defined as an embodied and collective knowledge in classrooms and communities (Schwarze, 1999). These activities help to cultivate the practical wisdom that successful collaboration requires (Flyvbjerg, Landman, \& Schram, 2012).

Practice-based pedagogy for collaboration

EC has consistently demonstrated how praxis-based communication training supports responses to pressing sustainability issues that are dynamic, situated, inclusive, and potentially sustainable (Druschke et al., 2015; Endresetal., 2008). Here we consider praxis by scale, focusing: (a) on individuals; (b) between individuals and within groups; and (c) within situations, organizations, and socioecologies.

Individual reflective practice

Scholarship on collaboration tends to emphasize group communication, whereas activities at the individual level have received comparatively little attention (Stokols, 2014). Focusing on the individual level is crucial because "value commitments are the motivational core that supports and maintains a variety of attitudes, beliefs, conceptual approaches, and behaviors that are mutually consistent with one another and jointly constitute the [transdisciplinary] intellectual orientation" (Stokols, 2014, p. 63). The activities we offer as follows can help train students "to 
foster reflective habits of mind" (Yancey 1998, p. vi), to "learn how to think well; especially how to acquire the general habit of reflecting" (Dewey, 1993, p. 34). Reflection then is about actively considering values, motivations, power, and positionality. Individual activities can encourage critical reflection on values and subject positions. For example, the Toolbox method encourages collaborators to identify, evaluate, and create new research paradigms (Eigenbrode et al., 2007; Winowiecki et al., 2011). In this dialogic method, individuals respond to questions and explore ontological, epistemological, and methodological commitments in ways that help them prepare for interactions that promote creativity from these differences.

Active reflection helps address disciplinary differences that, if left unacknowledged, can inhibit mutual understanding. In interdisciplinary contexts, power is expressed in the performance of subject positions when social scientists and biophysical scientists, professors and students, academics and practitioners attempt to work together (MacMynowski, 2007). Asking critical questions and promoting reflection recognizes that "interdisciplinary endeavors begin and end with a meeting of values, worldviews, claims, to know something about something" (MacMynowski, 2007, p. 4). In collaborative activities, people with complex subjectivities deliberate and negotiate value differences to produce knowledge, and power is at the heart of these deliberative processes. As Yancey (1998) describes, a dialectical approach to bringing multiple perspectives together "help[s] us understand how something completed looks later, how it compares with what has come before, how it meets stated or implicit criteria, our own, those of others" (Yancey 1998, p. 6). Critical reflection helps collaborators attend to how they help (re)produce or transform power relations. 
Interpersonal communication capacities

Interpersonal and group skills allow collaborators to attend to how communication shapes individual experiences, group formation, and diverse outcomes. Communication practices that demonstrate presence and reflexivity, promote shared laughter, encourage statements that challenge and productively explore social differences, and inspire collaborators to follow up with each other "backstage" to continue to find ways to work through difference can all enhance collaborations (Thompson, 2009). Collaborations are undermined by negative practices in which collaborators use sarcasm, demonstrate blatant boredom, engage in power struggles, and challenge each other's expertise. Activities that help collaborators build trust and confront communication issues from the outset can promote interpersonal skill sets that improve satisfaction with the process, mutual understanding, team-based learning, and progress toward sustainability-related goals (McGreavy et al., 2015; Thompson, 2009).

Discussions of science communication that emphasize framing (Dewulf, François, Pahl-Wostl, \& Taillieu, 2007), context (Gross, 1994), and relationship building (Burke et al., 2016) support collaborative praxis at the group level. Burke and colleagues' (2016) model demonstrates how engaged science writing through a collaborative weekly news column can provide access to scientists and scientific information in ways that build relationships and promote knowledge coproduction. This is a clear example of how writing can build collaborative capacity by enhancing science literacy and strengthening interpersonal relationships.

Attunement within situations, organizations, and socioecologies 
Communication praxis at this third level is about connection, attunement, and intervention in established organizations, within dynamic situations, and as part of broader socioecologies. As Caron and Serrell (2009) argue, “understanding a community’s ecology is essential for practitioners to help build a community's capacity to address a wicked problem" (p. 201). We build from systems approaches, where attunement means equipping students and participants to attend to individuals' and groups' embeddedness in wider systems and to dynamic interactions among system components, fostered by individual and group activities at the first two levels. Individual critical reflection can include consideration of the individual within larger systems, while a group activity that encourages statements that productively explore social differences can advance conversations about larger structural issues. These skills can help people progressively contextualize social and environmental change and identify needs for further information and policy action (Vayda, 1983). This approach starts "with actions or interactions of individual living things and can proceed to put them in contexts that make the actions or interactions intelligible by showing their place within complexes of causes and effects" (Vayda, 1983, p. 270). Doing so requires careful attention to myriad details across space and time and, thus, systems-focused activities can be difficult to envision and implement yet are crucial for fostering meaningful transformations for sustainability (Vayda \& Walters, 1999).

Training students in connection, attunement, and intervention allows them to learn about and respond to particular situations or ecologies. Our focus on activities in the next section emphasizes a central commitment in our pedagogy that strives for the cultivation of practical wisdom. Individual and interpersonal skill development promotes empowered decision making 
within a given situation, yet we are limited in our ability to offer a general theory for how collaborative praxis realizes itself because of the emphasis of phronesis on "the contingencies of particular, practical situations" (Schwarze, 1999, p. 78). We emphasize both the deliberative and performative dimensions of practical wisdom (Schwarze, 1999), by focusing in the classroom and beyond.

Praxis-based activities for collaborations in diverse contexts

The following activities, across multiple contexts, have enabled us to teach in meaningful ways, build partnerships, and work toward solving sustainability-related problems. We describe them here and have incorporated them in a flexible yet tailored interpretive framework for designing and assessing activities that build specific EC capacities (Table 1).

Activity 1: Frame within a frame

This activity introduces how frames shape the ways collaborators understand issues and negotiate differences (Dewulf et al., 2007;Lakoff, 2010). This activity requires access to Istvan Banyai's (1998) Zoom and a participant observation checklist of collective communication competencies (Thompson, 2009). Zoom, a picture book, starts with an image at a fine scale and scrolls out to the cosmos. This activity includes two roles: framers and ethnographers. Framers each receive at least one photocopy of a page in Zoom. Participants cannot show their page to anyone else and can only describe their frame to others. They work as a group to put the pages in the correct order from the finest to coarsest scale while a small group of ethnographers observe, 
using the checklist of communication competencies to guide their observations. Once the framers think they have the correct sequence, participants display their pages and reflect on the group communication. Ethnographers share supportive observations to help the group talk about their experiences. A facilitator may need to encourage open dialogue about negative communication competencies like power struggles and challenging expertise by posing questions such as: How did the decision making occur and how did that go for you? Did you feel heard? How do you feel about the process and outcomes?

Activity 2: Cardstorming

This brainstorming exercise helps generate new ways of thinking and deeper analysis of issues. Participants receive a prompt (e.g., What makes this community inclusive? What assets does this community have for building resilience?) and a set of post-it notes (three to seven), and are asked to write a separate answer to the prompt on each post-it. Initially, the focus should be on each person generating multiple responses to the prompt rather than critiquing answers produced. Participants then form groups of four to seven people. These groups look through all the post-its written by group members and use them as inventional resources for generating another round of responses (10 to 15) that aim to deepen and expand the range of answers. This process can be continued several times until the group has brainstormed a broad range of responses. The post-it notes from all groups are then put onto a shared wall, and participants categorize the notes into themes. When used in a classroom, this categorization can help students practice the basics of qualitative coding and pattern development. In a community setting, it can help develop inductive categories to organize main ideas. 
Activity 3: Our shared history

In this timeline building activity, participants contribute to a wall-sized timeline (e.g., $4 \times 12$ feet of white butcher paper taped to a wall) identifying key ecological, political, and cultural aspects of an issue. This activity encourages all team members to write what they know about the local issue or system being studied, and how social and environmental factors are connected over the course of time (e.g., writing when a specific policy was introduced and then noticing the change in air or water quality in years following regulation). The goal is not to write the history-book version of an issue, but present and build a collaborative record of the many histories influencing a local system. This activity is useful in the early phase of a collaborative project, for either EC students assigned to a local issue or community stakeholders working in a cross-institutional partnership.

Activity 4: Places for rhetoric

This activity emphasizes how places shape social interactions, as place is "a performer along with [us] in making and unmaking the possibilities of [actions that occur here]" (Endres \& Senda-Cook, 2011, p. 258). This activity helps collaborators attend to how the characteristics of a place, like the size and shape of the room; the amount, timing, and quality of food; the presence, absence, or "failure" of communication technologies; among many other materialities, shape group efforts. Participants learn how to attend to the vibrant, participatory quality of the world (Bennett, 2010;Milstein, 2008) and in doing so may also start to explore "humans' 
immersion and participation in natural systems" in ways that dismantle "boundaries that exclude "nature" from communicative and other social processes" (Rogers, 1998, p. 247). This activity becomes an entry point to experience transformative internatural relationships (e.g., Plec, 2013) and to identify ways of living ethically with and within a broader community of Earth's inhabitants (Callister, 2013; Peterson, Peterson, \& Peterson, 2007). It is in this redefined space of sensory awareness that we may find new ways of being with the more-than-human entities, both living and nonliving, that enrich and sustain us (Carbaugh, 1999; Salvador \&Clarke, 011; Schutten \& Rogers, 2011).

In a classroom-based setting, the instructor sends students outside to take field notes about how people move through various spaces on campus and activities that occur. They observe hallways, common areas, and classrooms, attending to the physical arrangement, and note how configurations of space enable or constrain movement and communication. Where do people talk and where are they silent? How do they move through space? Who or what else shows up and how do material features shape what happens here? These observations help participants attend to how place and materiality matter in collaboration.

Activity 5: All work together

This activity, and our paper, takes the title of Woody Guthrie's famous song to heart: there are "all kinds of work [we] can do," and builds from an understanding of rhetoric as "a bodily, habituated practice dependent upon rhythm, repetition, and response" (Hawhee, 2004, p. 193). This activity grows from the ancient notion that rhetoric is performed, understood, and enacted 
bodily, and modern ideas that focus on the forms of learning that emerge from the process of participating in everyday practice (Lave, 1993; Wenger, 1998). While activities vary, they all feature collaborators gathering bodies together to engage in physical, sustainability-oriented work. These projects matter because "environmental project[s] focused on local solutions to global problems [are] not only a great learning experience for students," they also provide "an effective method of accelerating socially responsible technologies" (Pearce \& Russill, 2005, p. 71). Examples from our contexts include research lab members participating in a local river cleanup at the outset of a multi-year research collaboration about wetland restoration; a women's-only agricultural walking tour where participants engage conservation staff; a schoolyard BioBlitz organized by college students for community members; or participation in a rally for environmental justice. In the doing together teaching collaboration gets done too.

Activity 6: Composing our way to collaboration

These activities focus on the act of composing together as a collaborative strategy. Team members work on a common composing project, like a grant proposal, Web site, or chapter about EC pedagogy. Students and participants write with each other and community partners (Deans, 2000), benefiting from the collaborative writing process (Ede \& Lunsford, 1990) by entering into the collective work of engagement, the individual work of imagination, and the institutional work of alignment to create communities of practice (Wenger, 1998). The process should help participants identify, "terms that reveal the strategic spots at which ambiguities necessarily arise" (Burke, 1969, p. xviii). This can help team members identify beyond differences to set objectives, map concepts, and draft missions. 
Students and collaborators may also compose collaboratively by selecting, justifying, and performing appropriate and consequential interventions. Projects may include letters to the editor, lessons taught at local schools, acts of civil disobedience, and participatory mapping projects.

Situated assessment and creative application

We encourage taking a "backwards design” approach (Wiggins \& McTighe, 2005), deliberately designing activities and frameworks based on intended outcomes that might include critical reflection, framing, science content, and interpersonal competencies (Table 1). EC pedagogy can emphasize a kairotic approach based on a dynamic sense of timing, appropriateness, and urgency; cultivate mindfulness about community needs; seek a balance between strategic and tactical approaches; and encourage experimentation, risk, and reflection (Druschke et al., 2015). Backwards design pairs well with progressive contextualization introduced previously, as both encourage teachers to go beyond narrow disciplinary training to include the content, skills, and evaluation techniques that are most appropriate for a particular situation (Vayda, 1983).

Teachers can adapt the practice of reflective writing to encourage students and community members to become critical participants who reflect on and analyze their participation through EC and rhetorical perspectives. If we want participants to identify best practices, formulate action plans, become more familiar with potential collaborators, ask rich questions, and intervene in public matters, we can employ rhetorical analyses - attentive to audience, consequence, style, 
motive, delivery, and exigence - that support critical reflection. The use of phronetic reflection offers a way to assess whether and how activities allow students, participants, and teachers to cultivate the deliberative and performative practical wisdom that successful collaboration requires. Serving both practical and normative ends, phronetic reflection helps build the core capacities we have focused on here through excellence in teaching and learning and respond to EC's call as a crisis discipline to advance sustainability (Cox, 2007).

\section{Conclusion}

These activities promote outcomes that support EC's commitment to addressing crises, critiquing and transforming social and environmental injustices, and promoting diversity in socioecological communities (Cox, 2007; Endresetal., 2008). These activities have helped the authors realize commitments to crisis intervention, justice, and diversity in personally and professionally meaningful ways.

In Colorado, Sprain has used Cardstorming (Activity 2) to help first-year students understand how their communication practices make their community more inclusive, which enabled them to make connections between their communication and the socioecological system of which they were a part. In Maine, McGreavy, along with shellfishermen, regulators, students, and other partners, wrote a grant (Activities 5 and 6) to create an informal organization that has helped track and fix longstanding pollution sources, improve water quality, open 138 acres of closed clamflats, and build capacity for sustainable shellfish management in a culture, industry, ecosystem facing many threats. Lindefeld has developed a deep commitment to intentional 
activities that help collaborators identify framing issues together and engage in structured planning to integrate methods (Activity 1).

From Michigan to Mongolia, Thompson has worked with students and community partners to foster collaborative capacity at various levels of intimacy. From building shared timelines of climate-related issues (Activity 3), to facilitating team retreats with candid conversations about negotiating knowledge, relationships, and scientific approaches in a large-scale international collaboration, students and partners alike report a deep appreciation for learning more about the issues, the collaborative process, and themselves. Gottschalk Druschke coordinated a women's field day in Iowa where traditionally overlooked female agricultural landowners were invited to walk through neighboring farm fields while informally engaging with conservation staff (Activity 5). The event prompted a formal survey (Activity 6), which, by determining women had significantly different conservation knowledge and attitudes than men in the watershed, shaped conservation outreach toward women's particular needs.

These instances represent a small part of a body of work that equips students and collaborators to build the practical wisdom and form collaborations that matter. In our diverse contexts, we are frequently reminded of the labor that is always embedded within and part of collaboration. Sometimes this work is easy and enjoyable, and other times it requires great patience and effort. We see this as a necessary part of what it takes to work in interdisciplinary and transdisciplinary settings. Our activities are designed to productively engage this work and turn our collective labor in classrooms and community settings toward creating sustainable futures together. 
References

Banyai, I. (1998). Zoom. London, UK: Puffin Books.

Bennett, J. (2010). Vibrant matter: A political ecology of things. Durham, NC: Duke University Press.

Burke, B. J., Welch-Devine, M., Gustafson, S., Heynen, N., Rice, J. L., Gragson, T. L., \& Nelson, D. R. (2016). Beyond problem solving: Reconceptualizing the work of public deliberation as deliberative inquiry. Communication Theory, 26(1), 41-63. doi:10.1111/comt.12055

Burke, K. (1969). A grammar of motives. Berkeley, CA: University of California Press.

Callister, D. C. (2013). Land community participation: A new “public" participation model. Environmental Communication, 7(4), 435-455. doi:10.1080/17524032.2013.822408

Carbaugh, D. (1999). “Just listen”: “Listening” and landscape among the Blackfeet. Western Journal of Communication, 63(3), 250-270. doi:10.1080/10570319909374641

Carcasson, M. (2010). Facilitating democracy: Centers and institutes of public deliberation and collaborative problem solving. New Directions for Higher Education, 2010(152), 51-57.

Carcasson, M., \& Sprain, L. (2016). Beyond problem solving: Reconceptualizing the work of public deliberation as deliberative inquiry. Communication Theory, 26(1), 41-63. doi:10.1111/comt.12055

Caron, R. M., \& Serrell, N. (2009). Community ecology and capacity: Keys to progressing the environmental communication of wicked problems. Applied Environmental Education \& Communication, 8(3-4), 195-203. Retrieved from http://doi.org/10.1080/ 15330150903269464 
Cobb, A. N., \& Thompson, J. L. (2012). Climate change scenario planning: a model for the integration of science and management in environmental decision-making. Environmental Modelling \& Software, 38, 296-305.

Cox, R. (2007). Nature's “crisis disciplines": Does environmental communication have an ethical duty? Environmental Communication, 1(1), 5-20.

Cox, R., \& Depoe, S. (2015). Emergence and growth of the 'field' of environmental communication. In A. Hansen \& R. Cox (Eds.), The Routledge Handbook of Environment and Communication (pp. 13-25). New York, NY: Routledge.

Daniels, S. E., \& Walker, G.B. (2001). Working through environmental conflict: The collaborative learning approach. Westport, CT: Praeger Publishers.

Deans, T. (2000). Writing partnerships: Service-learning in composition. Urbana, IL: National Council of Teachers of English.

Depoe, S. P., Delicath, J. W., \& Elsenbeer, M. F. A. (2004). Communication and public participation in environmental decision making. Albany, NY: State University of New York Press.

Dewey, J. (1993). How we think (2nd ed.). Boston. MA: D. C. Heath.

Dewulf, A., François, G., Pahl-Wostl, C., \& Taillieu, T. (2007). A framing approach to crossdisciplinary research collaboration: Experiences from a large-scale research project on adaptive water management. Ecology and Society, 12(2), 14. Retrieved from http://www.ecologyandsociety.org/vol12/iss2/art14/

Druschke, C. G., Bolinder, M. M., Pittendrigh, N., \& Rai, C. (2015). Designing the future: assessing long-term impact of service-learning on graduate instructors. Reflections: $A$ Journal of Public Rhetoric, Civic Writing, and Service Learning, 14(2), 22-50. 
Druschke, C. G., \& Hychka, K. C. (2015). Manager perspectives on communication and public engagement in ecological restoration project success. Ecology and Society, 20(1), 58. http://dx.doi.org/10.5751/ES-07451-200158

Druschke, C. G., \& Seltzer, C. E. (2012). Failures of engagement: Lessons learned from a citizen science pilot study. Applied Environmental Education \& Communication, 11(3-4), 178188.

Ede, L. S., \& Lunsford, A. A. (1990). Singular texts/plural authors: Perspectives on collaborative writing. Carbondale, IL: SIU Press.

Eigenbrode, S. D., O’Rourke, M., Wulfhorst, J. D., Althoff, D. M., Goldberg, C. S., Merrill, K., Bosque-Pérez, N. A. (2007). Employing philosophical dialogue in collaborative science. BioScience, 57(1), 55-64. doi: 10.1641/B570109

Endres, D., \& Senda-Cook, S. (2011). Location matters: The rhetoric of place in protest. Quarterly Journal of Speech, 97(3), 257-282.

Endres, D., Sprain, L., \& Peterson, T. R. (2008). The imperative of praxis-based environmental research: Suggestions from the Step It Up 2007 National Research Project. Environmental Communication, 2, 237-245.

Flyvbjerg, B., Landman, T., \& Schram, S. (Eds.). (2012). Real social science: Applied phronesis. New York, NY: Cambridge University Press.

Gross, A. G. (1994). The roles of rhetoric in the public understanding of science. Public Understanding of Science, 3(1), 3-23.

Haskins, E. (2006). Choosing between Isocrates and Aristotle: Disciplinary assumptions and pedagogical implications. Rhetoric Society Quarterly, 36(2), 191-201. Retrieved from http://www.jstor.org.prxy4.ursus.maine.edu/stable/3886176 
Hawhee, D. (2004). Bodily arts: Rhetoric and athletics in ancient Greece. Austin, TX: University of Texas Press.

Hawhee, D. (2009). Moving bodies: Kenneth Burke at the edges of language. Columbia, SC: University of South Carolina Press.

Klein, J. T. (2014). Communication and collaboration in interdisciplinary research. In M.O. O’Rourke, S. Crowley, S. D. Eigenbrode, \& J. D. Wulfhorst (Eds.), Enhancing communication \& collaboration in interdisciplinary research (pp. 11-32). Thousand Oaks, CA: Sage Publications.

Lakoff, G. (2010). Why it matters how we frame the environment. Environmental Communication: A Journal of Nature and Culture, 4(1), 70-81. Retrieved from http://doi.org/10.1080/17524030903529749

Lave, J. (1993). The practice of learning. In S. Chaiklin \& J. Lave (Eds.), Understanding practice (pp. 3-32). New York, NY: Cambridge University Press.

Lemieux, C. J., Thompson, J., Slocombe, D. S., \& Schuster, R. (2015). Climate change collaboration among natural resource management agencies: Lessons learned from two US regions. Journal of Environmental Planning and Management, 58(4), 654-677.

Lindenfeld, L. A., Hall, D. M., McGreavy, B., Silka, L., \& Hart, D. (2012). Creating a place for environmental communication research in sustainability science. Environmental Communication, 6(1), 23-43. doi:10.1080/17524032.2011.640702

MacMynowski, D. P. (2007). Pausing at the brink of interdisciplinarity: Power and knowledge at the meeting of social and biophysical science. Ecology and Society, 12(1), 20. Retrieved from http://www.ecologyandsociety.org/vol12/iss1/art20/ 
McGreavy, B., Lindenfeld, L., Bieluch, K., Silka, L., Leahy, J., \& Zoellick, B. (2015).

Communication and sustainability science teams as complex systems. Ecology and Society, 20(1), 2. Retrieved from http://dx.doi.org/10.5751/ES-06644-200102

Milstein, T. (2008). When whales "speak for themselves": Communication as a mediating force in wildlife tourism. Environmental Communication, 2(2), 173-192.

O’Rourke, M., Crowley, S., Eigenbrode, S. D., \& Wulfhorst, J. D. (Eds.). (2014). Enhancing communication \& collaboration in interdisciplinary research. Thousand Oaks, CA: Sage Publications.

Pearce, J. M., \& Russill, C. (2005). Interdisciplinary environmental education: Communicating and applying energy efficiency for sustainability. Applied Environmental Education Communication, 4(1), 65-72. Retrieved from http://doi.org/10.1080/15330150590911412

Peterson, M. N., Peterson, M. J., \& Peterson, T. R. (2007). Environmental communication: Why this crisis discipline should facilitate environmental democracy. Environmental Communication, 1(1), 74-86. Retrieved from http://doi.org/10.1080/17524030701334292

Plec, E. (Ed.) (2013). Perspectives on human-animal communication: Internatural communication. New York, NY: Routledge.

Rogers, R. A. (1998). Overcoming the objectification of nature in constitutive theories: Toward a transhuman, materialist theory of communication. Western Journal of Communication, 62(3), 244-272. doi: 10.1080/10570319809374610

Rudeen, A., Fernandez-Gimenez, M., Thompson, J. L., \& Meiman, P. (2012). Perceptions of success and the question of consensus in natural resource collaboration: Lessons from an inactive collaborative group. Society \& Natural Resources, 25(10), 1012-1027. 
Salvador, M., \& Clarke, T. (2011). The Weyekin Principle: Toward an embodied critical rhetoric. Environmental Communication, 5(3), 243-260. Retrieved from http://doi.org/10.1080/17524032.2011.586713

Schutten, J. K., \& Rogers, R. A. (2011). Magick as an alternative symbolic: Enacting transhuman dialogs. Environmental Communication, 5(3), 261-280. Retrieved from doi:10.1080/17524032.2011.583261

Schwarze, S. (1999). Performing phronesis: The case of Isocrates' "Helen.” Philosophy \& Rhetoric, 32(1), 78-95.

Sprain, L., Carcasson, M., \& Merolla, A. (2014). Experts in public deliberation: Lessons from a deliberative design on water needs. Journal of Applied Communication Research, 42, $150-167$.

Sprain, L., \& Timpson, W. (2012). Pedagogy for sustainability science: Case-based approaches for interdisciplinary instruction. Environmental Communication, 6, 532-550.

Stokols, D. (2014). Training the next generation of transdisciplinarians. In M. O. O'Rourke, S. Crowley, S. D. Eigenbrode, \& J. D. Wulfhorst (Eds.), Enhancing communication \& collaboration in interdisciplinary research (pp. 56-81). Los Angeles, CA: Sage Publications.

Thompson, J. L. (2009). Building collective communication competence in interdisciplinary research teams. Journal of Applied Communication Research, 37(3), 278-297.

Thompson, J. L., Forster, C. B., Werner, C., \& Peterson, T. R. (2010). Mediated modeling: Using collaborative processes to integrate scientist and stakeholder knowledge about greenhouse gas emissions in an urban ecosystem. Society \& Natural Resources, 23(8), 742-757. 
Tilbury, D., \& Wortman, D. (2008). How is community education contributing to sustainability in practice? Applied Environmental Education \& Communication, 7(3), 83-93. Retrieved from http://doi.org/10.1080/15330150802502171

Vayda, A. P. (1983). Progressive contextualization: Methods for research in human ecology. Human Ecology, 11(3), 265-281.

Vayda, A. P., \& Walters, B. B. (1999). Against political ecology. Human Ecology, 27(1), 167179.

Wenger, E. (1998). Communities of practice: Learning, meaning, and identity. New York, NY: Cambridge University Press.

Wiggins, G., \& McTighe, J. (Eds.). (2005). Understanding by design (2nd ed.). New York, NY: Pearson.

Winowiecki, L., Smukler, S., Shirley, K., Remans, R., Peltier, G., Lothes, E., \& Alkema, L. (2011). Tools for enhancing interdisciplinary communication. Sustainability: Science, Practice, \& Policy, 7(1), 74-80.

Yancey, K. B. (1998). Reflection in the writing classroom. Logan, UT: Utah State Univ. Press 
Table 1. Framework to orient the design and assessment of environmental communication activities that build specific collaborative capacities for sustainability.

\begin{tabular}{|c|c|c|c|c|c|c|}
\hline & $\begin{array}{l}\text { (1) Frame w/ln } \\
\text { a Frame }\end{array}$ & Cardstorming & $\begin{array}{l}\text { (3) Our shared } \\
\text { history }\end{array}$ & $\begin{array}{l}\text { (4) Places } \\
\text { for rhetoric }\end{array}$ & $\begin{array}{l}\text { (5) All working } \\
\text { together }\end{array}$ & $\begin{array}{l}\text { (6) Composing } \\
\text { our way to } \\
\text { collaboration }\end{array}$ \\
\hline Group size & 40 & $10-50$ & $5-50$ & 40 & $2-20$ & $2-5$ \\
\hline $\begin{array}{l}\text { Ideal timing during a } \\
\text { collaborative effort }\end{array}$ & any & any & & any & early, any & any \\
\hline \multicolumn{7}{|l|}{ Context and roles } \\
\hline Classrooms & $\mathrm{x}$ & $\mathrm{x}$ & $\mathrm{x}$ & $\mathrm{x}$ & $\mathrm{x}$ & $\mathrm{X}$ \\
\hline Research teams & $\mathrm{x}$ & $\mathrm{x}$ & $\mathrm{x}$ & $\mathrm{x}$ & $\mathrm{x}$ & $\mathrm{x}$ \\
\hline Interested cittzens & $\mathrm{x}$ & $\mathrm{x}$ & $\mathrm{x}$ & $\mathrm{x}$ & $\mathrm{x}$ & $\mathrm{x}$ \\
\hline $\begin{array}{l}\text { Community } \\
\text { organizations }\end{array}$ & $\mathrm{x}$ & $\mathrm{x}$ & $\mathrm{x}$ & $\mathrm{x}$ & $\mathrm{x}$ & $\mathrm{X}$ \\
\hline Businesses & $\mathrm{x}$ & $\mathrm{x}$ & $\mathrm{x}$ & $\mathrm{x}$ & $\mathrm{x}$ & $\mathrm{x}$ \\
\hline $\begin{array}{l}\text { Governmental (elected \& } \\
\text { appointed, across } \\
\text { scales) }\end{array}$ & & $\mathrm{x}$ & $\mathrm{x}$ & & $\mathrm{x}$ & $\mathrm{x}$ \\
\hline \multicolumn{7}{|l|}{ EC Praxis Commitments } \\
\hline Critical reflection & $\mathrm{x}$ & $\mathrm{x}$ & $\mathrm{x}$ & $\mathrm{x}$ & & $\mathrm{x}$ \\
\hline $\begin{array}{l}\text { Environmental and } \\
\text { sclence literacy } \\
\text { (content and writing) }\end{array}$ & & & $\mathrm{X}$ & & $\mathrm{x}$ & $\mathrm{X}$ \\
\hline $\begin{array}{l}\text { Framing and symbolic } \\
\text { construction }\end{array}$ & $\mathrm{x}$ & & & $\mathrm{X}$ & & $\mathrm{X}$ \\
\hline Interactional expertise & $\mathrm{x}$ & $\mathrm{x}$ & & & $\mathrm{x}$ & $\mathrm{x}$ \\
\hline $\begin{array}{l}\text { Interpersonal practices } \\
\text { (demonstrate } \\
\text { Ilstening, respect, } \\
\text { laughing together) }\end{array}$ & $\mathrm{x}$ & $\mathrm{X}$ & & $\mathrm{x}$ & $\mathrm{x}$ & $\mathrm{x}$ \\
\hline Spatial awareness & $\mathrm{x}$ & & & $\mathrm{x}$ & & \\
\hline $\begin{array}{l}\text { Systems thinking and } \\
\text { problem solving }\end{array}$ & & $\mathrm{x}$ & & & & \\
\hline $\begin{array}{l}\text { Sensing windows of } \\
\text { opportunity — kalros } \\
\text { and phronesis }\end{array}$ & & & & & $\mathrm{x}$ & $\mathrm{x}$ \\
\hline
\end{tabular}

Note. The group sizes, timing, contexts, and praxis commitments reflect how we have used these activitles, and we encourage active experimentation for new applications and skill development. 